\title{
Poetic justice in Obadiah
}

It has often been noted that Obadiah is a book concerned with lex talionis, an idea which is made explicit in Obad. 15b: 'As you have done, it shall be done to you; your deeds shall return on your own head'. ${ }^{1}$ However, when we look closely at the Hebrew text, we can see that this sense of justice is not simply one of Obadiah's themes; it is actually embedded in the language of the book itself. ${ }^{2}$ This 'poetic justice' takes place via a series of allusions and word plays, some overt and others less so, which add to the rhetorical force of Obadiah's message. For heuristic purposes these word plays and allusions have been grouped below into two categories: those which juxtapose the identities and futures of those involved, namely Edom and Judah; and those which allude to Edom's reckoning in light of her actions toward Judah.

\footnotetext{
${ }^{1}$ All biblical quotations are from the NRSV unless stated otherwise.

${ }^{2}$ As these word plays and allusions occur throughout the book, this article will focus on the received form of the text. The compositional history and literary integrity of Obadiah are dealt with at length in the major commentaries, as well as Ehud Ben Zvi, A Historical-Critical Study of the Book of Obadiah (BZAW 242; Berlin: Walter de Gruyter, 1996); Theodor Lescow, 'Die Komposition des Buches Obadja', ZAW 111 (1999), pp. 389-392; G. Fohrer, 'Die Sprüche Obadjas', in Studia biblica et semitica Theodoro Christiano Vriezen dedicata (ed. Wilhelm C. van Unnik and Adam Simon van der Woude; Wageningen: H. Veenman, 1966), pp. 81-93; and S.D. Snyman, 'Cohesion in the Book of Obadiah', $Z A W 101$ (1989), pp. 59-71. The present work also focuses primarily on literary aspects of Obadiah. For more on the historical setting and Sitz im Leben, consult J.R. Bartlett, 'Edom and the Fall of Jerusalem, 587 B.C.', PEQ 114 (1982), pp. 13-24; J.M. Myers, 'Edom and Judah in the Sixth-Fifth Centuries B.C.', in Near Eastern Studies in Honor of William Foxwell Albright (ed. Hans Goedicke; Baltimore: John Hopkins University Press, 1971), pp. 377-392; Hans Walter Wolff, 'Obadja - ein Kultprophet als Interpret', EvTh 37 (1977), pp. 273-284.
} 


\section{Juxtaposed Identities and Futures}

The book of Obadiah is concerned not only with the downfall of Edom, but also with Judah's restoration. One way the case against Edom is made is by drawing on the history that the two peoples share. To begin with, reference is made to Esau (Obad. 6) and his brother Jacob (Obad. 10), explicitly noting the patriarchs of the respective peoples involved, as well as their kinship. ${ }^{3}$ This familial connection is a large part of Obadiah's indictment of Edom, as seen in Obad. 10-11: 'For the slaughter and violence done to your brother Jacob (יעקב אחידי), shame shall cover you, and you shall be cut off for ever. On the day that you stood aside, on the day that strangers (זים) carried off his wealth, and foreigners (רונכרים) entered his gates and cast lots

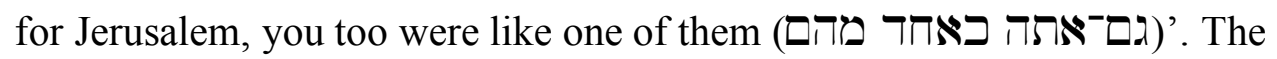

\footnotetext{
${ }^{3}$ While one cannot say conclusively whether or not Obadiah is drawing on Genesis itself, there are several other allusions in the text that might point the reader in this direction. In vs. 2 , for example, we read, 'I will surely make you least (קטן) among the nations; you shall be utterly despised (בז)'. The reference to Edom being 'least' among the nations may be an allusion to the reversal of the birth order of Jacob and Esau, where the elder brother was displaced by the younger one (see Gen. 27.15 and 42 , where Esau is referred to as the elder [הגדל] son, while Jacob is the younger, or 'small' one [הטקט]). The subsequent reference to Edom being 'despised', which stands in parallel to the description of 'least', reminds the reader of Gen. 25.34, which states that Esau despised (ריבּ) his birthright. Thus, the elder brother is now regarded as insignificant, and the one who despised the birthright is now despised by others. On the possible historical development of this 'brotherhood' tradition, see J.R. Bartlett, 'The Brotherhood of Edom', JSOT 4 (1977), pp. 2-27.
} 
implication of these verses is that, in the eyes of Judah, Edom has acted more like the foreign peoples than a brother, an indictment which the text implies is reason enough for Edom's coming downfall.

Another image that highlights the juxtaposition of these 'brothers' and captures the reversal of fortune for Judah and Edom is found in Obad. 18. Here the text parallels the 'house of Jacob' and the 'house of Joseph' with the 'house of Esau'. Using a series of terms related to 'fire', it reads, 'The house of Jacob shall be a fire (UN), the house of Joseph a flame (להבה), and the house of Esau stubble (ל קשי); they shall burn them and consume them (ודלקו בהם ואכל ום)'. In this vision of the future, a unified Israel ('Jacob' representing Judah and 'Joseph' the northern Israelite tribes) is the fire and flame that burns and consumes 'Esau', reducing it to mere stubble. ${ }^{4}$ Thus, not only will Esau's descendants be destroyed, but Jacob's progeny will also return to an idyllic state, their full inheritance restored..$^{5}$

Secondly, Obadiah juxtaposes identity with the use of geographical references. To parallel 'Mount Zion', Obadiah uses the hapax legomenon 'Mount Esau' in Obad. 21,

\footnotetext{
${ }^{4}$ See Paul R. Raabe, Obadiah: A New Translation with Introduction and Commentary (AB 24D; New York: Doubleday, 1996), p. 247; Hans Walter Wolff, Obadiah and Jonah (trans. Margaret Kohl; Minneapolis: Augsburg, 1986), pp. 65-66.

${ }^{5}$ This idea of a restored Israel is fleshed out in Obad. 19-20, where the four corners of the Davidic Israel are reclaimed as a 'possession'. See Johan Renkema, Obadiah (HCOT; trans. Brian Doyle; Leuven: Peeters, 2003), p. 215.
} 
perhaps a play on the more recognized designation 'Mount Seir'. ${ }^{6}$ Here Israel's holy mountain overtakes the mountain connected with Edom's ancestor.

Mount Zion plays a part in another allusion regarding the reversal of fortune for Edom and Judah. In Obad. 14 we read, 'You should not have stood at the crossings to cut off his [Judah's] fugitives'. The word rendered here as 'his fugitives' is פל יטיו, from פל יט, the masculine noun meaning 'escaped one' or 'fugitive'. A related noun occurs in Obad. 17a, where we read, 'But on Mount Zion there shall be those that escape (פל יטה), and it shall be holy'. Here the feminine noun is used, with the meaning 'escape' or 'deliverance'. Consequently, although Judah's 'escapees' were cut down by Edom, Mount Zion will one day be a place of 'escape' and deliverance.

Another juxtaposition regarding the geography of Edom and Judah is found in Obad. 17-20, based around the key term ירשי. While this term is employed in relation to a variety of peoples and places in these verses, the reversal of fortune concerning Edom and Judah is once again evident in this section. To begin with, there is a possible allusion to Edom in Obad. 17b. The reference revolves around a text critical issue in the second half of the verse, which reads, וירשו בית־יעקב את מורשידם. The issue at stake is the pointing of the final word; it is pointed מוֹרדיש ידים in BHS, where it is understood to be the noun מורש in the construct state with a 3mp suffix. This reading

\footnotetext{
${ }^{6}$ Raabe, Obadiah, pp. 164-165.

${ }^{7}$ Both nouns come from the root פל טל. See BDB, p. 812.
} 
suggests that the house of Jacob will repossess 'its possession', the land of Judah. However, several ancient variants understood this to be a hifil participle from ירש,, pointed מוֹרישי יהם, and translated as 'those who had possessed them', or 'their dispossessors', for which a likely candidate would obviously be Edom. This rendering is followed by the LXX, Vulgate, Peshitta, as well as ancient Hebrew manuscripts from Wadi Murabba'at. ${ }^{8}$ Thus, Obad. 17 refers to the house of Jacob either 'possessing its possession', or as 'dispossessing their dispossessors'.

Whatever ambiguity there might be in Obad. 17 is cleared up in Obad. 19, which begins by noting that 'Those of the Negeb shall possess (רירשו) Mount Esau'. Here it is the region closest to Edom, the Negeb, which is to possess Edom. ${ }^{9}$ It is natural to assume that if Edom made incursions into Judah, it would have been in the Negeb. Recent archaeological discoveries from the $9^{\text {th }}-6^{\text {th }}$ c. BCE have corroborated this, concluding that Edom did indeed over time develop a presence in the Negeb. ${ }^{10}$ This might explain why the Negeb is singled out as the possessor of Edom: those who took

\footnotetext{
${ }^{8}$ This variant reading is followed by Wolff (Obadiah and Jonah, p. 60) and Douglas Stuart (HoseaJonah [WBC 31; Waco: Word Books, 1987)], pp. 402-403), as well as the NRSV. Those that opt to follow the MT include Renkema (Obadiah, pp. 201-202) and Raabe (Obadiah, pp. 245-246), who both offer extended treatments, as well as the translations of the NIV and NASB.

${ }^{9}$ Renkema, Obadiah, p. 207.

${ }^{10}$ Itzhaq Beit-Arieh, 'New Data on the Relationship Between Judah and Edom Toward the End of the Iron Age', in Recent Excavations in Israel: Studies in Iron Age Archaeology (ed. Seymour Gitin and William G. Dever; Winona Lake: Eisenbrauns, 1989), pp. 125-131; J.M. Myers, 'Edom and Judah’, pp. 377-392; Renkema, Obadiah, pp. 34-35; Ben Zvi, Historical-Critical Study, pp. 266-267.
} 
possession of the Negeb will have the same done to them. ${ }^{11}$ Taken together, these two references (Obad. 17 and 19) make clear that the people Israel will repossess Judah, and Edom will be dispossessed from her land (and possibly displaced from Judah), another reversal of fortune for the Edomites.

In sum, Obadiah uses a series of corresponding designations for Edom and Judah that draw on their shared history (Esau/Jacob) and their geography (Mount Esau and Mount Zion). Moreover, these juxtapositions depict a reversal of fortune for both these peoples; 'brother' Edom will be dispossessed and purged, while Judah and Jerusalem will be repossessed, and will be a place of refuge for YHWH's people.

\section{Allusions to Edom's Reckoning}

A second set of word plays has to do with the retribution that awaits Edom because of its attitudes and actions with regard to Judah.

This reckoning can be seen from the very beginning of the book, where there is a play on the idea of 'high' and 'low'. Obad. 3-4 states, 'Your proud heart has deceived you,

\footnotetext{
${ }^{11}$ As Beth Glazier-McDonald comments, the "transformation of Edom from "an" enemy to "the" enemy is clearly attributed to Edom's movement from its own land to southern Judah, which is Yahweh's land' ('Edom in the Prophetical Corpus', in You Shall Not Abhor an Edomite For He is Your Brother: Edom and Seir in History and Tradition [ed. Diana Vikander Edelman; Atlanta: Scholars Press, 1995], p. 31).
} 
you that live in the clefts of the rock (בחגוייםסל ע), whose dwelling is in the heights (מרום). You say in your heart, "Who will bring me down (מי יורדני) to the

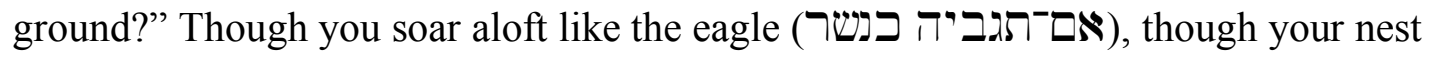

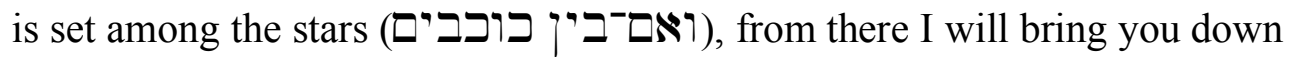
(\$ירדיד), says the LORD.' The connection of Edom with 'high places' is very likely rooted in the mountainous terrain associated with Edom and Seir (Gen. 36.6-8). Here, however, the heights has a double meaning: not only are the Edomites taking refuge in high places, but they are proud, a common biblical designation for those who make themselves 'high' when YHWH alone is to be high and exalted (see Is. 2:17). According to Obadiah, then, YHWH will bring Edom down, both physically and metaphorically.

At least two other word plays occur in these verses around this same theme. For example, Obad. 3 states of Edom that 'your proud heart has deceived you (השיאד)'. When we reach Obad. 7a, we are told that 'all your allies have deceived you (השיאוך)'. Hence, Edom's self-deception is juxtaposed with Edom's deception at the hands of its allies. Furthermore, in Obad. 4, we are told that Edom's nest 'is set (שים) among the stars'. In Obad. $7 \mathrm{~b}$, it is noted that 'those who ate your bread have set a trap for you (ישימו מזור תחתיךי)', and the Hebrew is clear that this trap is set 'under' them. Accordingly, as Edom imagines itself as 'set' beyond reach in the 
heights, its allies are 'setting' a trap under them, from below. ${ }^{12}$ In these two instances, Obadiah envisages Edom's false security as being preyed upon by none other than its allies, unlikely coworkers with YHWH in bringing Edom down from on high.

Another word play which reiterates the fact that Edom will get its comeuppance is the recurring use of the word 'day', $ם$ '. Obad. 11-14 speaks of Edom's actions on a particular 'day'. In vs. 11 the past tense is used: 'On the day (םיר) that you stood aside, on the day (ロיר) that strangers carried off his wealth...' Meanwhile, Obad. 12-14 uses vetitives. $^{13}$

But you should not have gloated over your brother [lit: "on the day of your brother," ] ביום־איץ] on the day (ביום) of his misfortune; you should not have rejoiced over the people of Judah on the day (ביום) of their ruin; you should not have boasted on the day

\footnotetext{
${ }^{12}$ An alternative reading of מזור in Obad. 7 is offered by P. Kyle McCarter ('Obadiah 7 and the Fall of Edom', BASOR 221 [1976], pp. 87-91), who notes that this word can be read as the noun 'stranger'. The sense of the verse is then, 'they have set strangers to replace you'. Cf. Raabe, Obadiah, pp. 154155. The word play on 'setting' (שים) is still evident in this reading: while Edom 'sets' itself on the heights, her allies 'set' others in their place. In point of fact, this reading raises another possible play on the word stranger in light of Obad. 11. Because Edom allowed ‘strangers' (ロיז) to carry off Judah's wealth (Obad. 11), 'strangers' (מזרור) will replace the Edomites (Obad. 7).

${ }^{13}$ As seen here, the NRSV uses a past tense, speaking of the events as if they have already happened. The NASB and NIV both use present tense to convey the prohibitive nature of the text. For more on this issue see Paul R. Raabe, 'Why Prophetic Oracles against the Nations?', in Fortunate the Eyes That See: Essays in Honor of David Noel Freedman in Celebration of His Seventieth Birthday (ed. Astrid B. Beck, et. al.; Grand Rapids: Eerdmans, 1995), pp. 243-246.
} 
(ביום) of distress. You should not have entered the gate of my people on the day (ביום) of their calamity; you should not have joined in the gloating over Judah's disaster on the day (ביום) of his calamity; you should not have looted his goods on the day (ביום) of his calamity. You should not have stood at the crossings to cut off his fugitives, you should not have handed over his survivors on the day (ロי ב) of distress.

These ten references to 'the day' of Edom's actions are enveloped by two references to the 'day' of YHWH's action in Obad. 8 and Obad. 15. In Obad. 8 we read, 'On that day (הל רוא ביום ההוא), says the LORD, I will destroy the wise out of Edom, and understanding out of Mount Esau'. ${ }^{14}$ The subsequent usage in Obad. 15 reads, 'For the day of the LORD (יוםייהוה) is near against all the nations. As you have done, it shall be done to you'. Thus, Edom's actions toward Judah 'on that day' are juxtaposed with YHWH's actions on the 'day of YHWH'. 15

We find two further allusions to Edom's future in light of their actions toward Judah in Obad. 14, which, as noted above, states, 'You should not have stood at the crossings to cut off (להכרית) his fugitives; you should not have handed over his survivors (שרידיר) on the day of distress'. To begin with, Obad. 9 and 10 both use the root כרתו, 'cut off', to describe what will be done to Edom, mirroring the usage of Obad. 14. In Obad. 9-10 we read, 'Your warriors shall be shattered, O Teman, so that

\footnotetext{
${ }^{14}$ The rendering in the NASB of 'Will I not on that day...' better captures the syntax of the phrase.

${ }^{15}$ For more on this theme, see Rolf Rendtorff, "Alas for the Day! The "Day of the LORD" in the Book of the Twelve', in God in the Fray: A Tribute to Walter Brueggemann (ed. Tod Linafelt and Timothy K. Beal; Minneapolis: Augsburg Fortress, 1998), pp. 186-197.
} 
everyone from Mount Esau will be cut off (יכרתיזיטישי). For the slaughter and violence done to your brother Jacob, shame shall cover you, and you shall be cut off (ונברת) forever'. A second resonance with Obad. 14 occurs in Obad. 18b, which states, "there shall be no survivor (שריד) of the house of Esau; for the LORD has spoken'. Thus, as Edom 'cut off’ Judah's fugitives (Obad. 14), so Edom will be ‘cut off' (Obad. 9-10). And as Edom handed over those 'survivors' from Judah's day of calamity (Obad. 14), so Edom itself will have no ‘survivors' (Obad. 18).

One final allusion to Edom's actions being returned upon them occurs in Obad. 16. Here the text reads, 'For as you have drunk (שת (שית) on my holy mountain, all the nations around you shall drink (ישתו); they shall drink and gulp down (רשתו ול עון), and shall be as though they had never been'. There are two main ways this double usage of 'drinking' can be understood, based in part around the question of who is in view in $16 a^{16}$ Several contemporary commentators argue that the first reference is best understood as Judah. ${ }^{17}$ If this reading is correct, then the sense of the verse is that just as Judah has drunk of the cup of YHWH's wrath, so will all the nations. An alternative reading is that which was followed by the preponderance of pre-modern interpretations (LXX, Targum, Rashi, Calvin), which understood this to refer to Edom, following on from Obad. 15. This approach seems to imply that Edom drank in

\footnotetext{
${ }^{16}$ See the summary in John Barton, Joel and Obadiah: A Commentary (OTL; Louisville: Westminster John Knox, 2001), pp. 151-152.

${ }^{17}$ Raabe, Obadiah, pp. 202-204. Cf. Jörg Jeremias, Die Propheten Joel, Obadja, Jona, Micha (ATD 24,3; Göttingen: Vandenhoeck \& Ruprecht, 2007), p. 72.
} 
revelry on Mount Zion, possibly in connection with the actions previously mentioned 'on that day'. The text goes on to state that this will be followed by the nations drinking from the cup of YHWH's wrath. In this reading there are two separate kinds of drinking: drinking in revelry, followed by drinking of YHWH's wrath. Whatever the case may be, in both readings a reversal of fortune is evident; either Edom and the nations will drink from the cup of YHWH as did Judah; or Edom's celebratory drinking on Mount Zion will be replaced with drinking from the cup of YHWH's wrath, along with the nations. ${ }^{18}$ Either way, the 'drinking' that is to come is not something that Edom should look forward to.

To review, the book of Obadiah contains several allusions which point toward Edom receiving retribution: 1) Edom will be brought 'down', even though they assume themselves to be on 'high'; 2) the 'day' of Edom's betrayal of Judah is juxtaposed with the 'day of YHWH' against Edom; 3) the 'cutting off' of Edom so that it has no 'survivor' is analogous to the 'cutting off' of Judah's 'survivors' by Edom; and 4) Edom and the nations will experience a reversal of fortune with regard to the 'drinking' which occurred on Mount Zion.

\section{Conclusion}

\footnotetext{
${ }^{18}$ See Raabe (Obadiah, pp. 206-242) for an extended discussion on the motif of drinking from the cup of YHWH's wrath.
} 
In summary, the short book of Obadiah contains a series of word plays, allusions and juxtapositions that embed its message of lex talionis in the content of the prophecy itself. These include juxtapositions concerning the identities of Edom and Judah and the futures that are in store for them, as well as the recompense which awaits Edom because of her actions. There are, to be sure, various ways in which the rhetorical function of Obadiah's message can be understood; ${ }^{19}$ there can be little doubt, however, about the literary artistry which reinforces Obadiah's message: Edom's deeds will indeed return upon her head.

\footnotetext{
${ }^{19}$ See, e.g., the ideological critique offered by Julia M. O'Brien (Challenging Prophetic Metaphor: Theology and Ideology in the Prophets [Louisville: Westminster John Knox, 2008], pp. 153-173), as well as the more sympathetic reading of Raabe (Obadiah, pp. 56-60).
} 